\title{
Concentrations and fluxes of dissolved organic carbon in runoff from a forested catchment: insights from high frequency measurements
}

\author{
S. Strohmeier ${ }^{1}$, K.-H. Knorr ${ }^{2}$, M. Reichert ${ }^{1,2}$, S. Frei ${ }^{2}$, J. H. Fleckenstein ${ }^{3}$, S. Peiffer ${ }^{2}$, and E. Matzner ${ }^{1}$ \\ ${ }^{1}$ Department of Soil Ecology, Bayreuth Center of Ecology and Environmental Research (BayCEER), University of Bayreuth, \\ 95440 Bayreuth, Germany \\ ${ }^{2}$ Department of Hydrology, Bayreuth Center of Ecology and Environmental Research (BayCEER), University of Bayreuth, \\ 95440 Bayreuth, Germany \\ ${ }^{3}$ Department of Hydrogeology, Helmholtz Center for Environmental Research (UFZ), 04318 Leipzig, Germany
}

Correspondence to: E. Matzner (egbert.matzner@uni-bayreuth.de)

Received: 14 August 2012 - Published in Biogeosciences Discuss.: 31 August 2012

Revised: 11 January 2013 - Accepted: 16 January 2013 - Published: 8 February 2013

\begin{abstract}
Concentrations of dissolved organic carbon (DOC) in runoff from catchments are often subject to substantial short-term variations. The aim of this study was to identify the compartmental sources of DOC in a forested catchment and the causes for short-term variations in runoff. Furthermore, we investigated the implication of short-term variations for the calculation of annual runoff fluxes. High frequency measurements ( $30 \mathrm{~min}$ intervals) of DOC in runoff, of discharge and groundwater table were conducted for one year in the $4.2 \mathrm{~km}^{2}$ forested Lehstenbach catchment, Germany. Riparian wetland soils represent about $30 \%$ of the catchment area. The quality of DOC was investigated by three dimensional fluorescence excitation-emission matrices in samples taken from runoff, deep groundwater and shallow groundwater from the riparian wetland soils. The concentrations of DOC in runoff were highly variable at an hourly to daily time scale, ranging from $2.6 \mathrm{mg} \mathrm{L}^{-1}$ to $34 \mathrm{mg} \mathrm{L}^{-1}$ with an annual average of $9.2 \mathrm{mg} \mathrm{L}^{-1}$. The concentrations were positively related to discharge, with a counter clockwise hysteresis. Relations of DOC to discharge were steeper and the degree of hysteresis larger in the summer/fall than in the winter/spring period. Dynamics of groundwater table, discharge, DOC concentrations and DOC quality parameters indicated that DOC in runoff originated mainly from the riparian wetland soils, both under low and high flow conditions. The annual export of DOC from the catchment was $84 \mathrm{kgCha}^{-1} \mathrm{yr}^{-1}$ when calculated from the
\end{abstract}

high frequency measurements. If the annual export was calculated by simulated samplings of $>2$ days intervals substantial deviations resulted.

Predicted changes in precipitation and discharge patterns as well as generally increasing temperatures likely will cause raising DOC exports from this catchment.

\section{Introduction}

The importance of dissolved organic carbon (DOC) for the functioning of terrestrial and aquatic ecosystems is widely known. DOC plays an important role in the $\mathrm{C}$ cycle, in the acid-base chemistry of soils and surface waters, it influences nutrient cycling, and affects the mobility and availability of metals and contaminants (Bolan et al., 2011; Kalbitz et al., 2000). Although numerous studies on DOC in soils and catchments have been published in the last decade, sources and sinks of DOC in soils and the transition of DOC from terrestrial to the aquatic ecosystems are still poorly understood in their quantitative response to driving factors, like climatic conditions, flow paths, vegetation and soil conditions.

DOC in runoff from forested catchments originates mostly from soil organic matter (Degens et al., 1991). Depending on precipitation, flow paths and catchment characteristics, different soil types and soil horizons from different parts of the catchment may feed the runoff with DOC, resulting in 
temporal variations of DOC quality and quantity in runoff. In general, the DOC export from forested catchments in Scandinavia was found to be positively related to the area of wetland soils (Laudon et al., 2011). To identify the compartmental sources of DOC in runoff, quality parameters of DOC can be used, like fluorescence spectroscopy (Ishii and Boyer, 2012; Fellman et al., 2009; Austnes et al., 2010). This is a highly sensitive method to determine changes in DOC quality and can be applied to a large number of samples.

DOC concentrations in runoff from forested catchments are often subjected to temporal variations of one order of magnitude at time scales ranging from hours to seasons. This can be attributed to the large differences in DOC concentrations in the two dominant flow components contributing to individual discharge events, i.e. groundwater versus shallow groundwater and surface runoff from riparian wetland soils (McGlynn and McDonnell, 2003; Hood et al., 2006). Ludwig et al. (1996) related the DOC fluxes to drainage intensity, basin slope, and the amount of carbon stored in soils. Interestingly, they found a negative relationship between basin slope and DOC concentrations as steeper slopes may cause a restricted contact between soil and water, and thus lead to lower DOC concentrations in runoff.

Hysteretic relationships between discharge and solute concentrations have observed, among others, by Hornberger et al. (1994), Evans and Davies (1998), Butturini et al. (2006), Raymond and Saiers (2010), Pellerin et al. (2012) and Jeong et al. (2012). Evans and Davies (1998) proposed the hysteretic concentration/discharge relationship for the analysis of episode hydrochemistry. Using a three component model, they categorized the concentration/discharge relationships into clockwise and counterclockwise hysteresis with a positive, negative or no trend. This categorization allows for the distinction of flow components that are drained during the rising or falling limbs of the hydrograph. Generally, high concentrations during the rising limb of the hydrograph lead to clockwise hysteresis, while high concentrations during the falling limb imply counterclockwise hysteresis. Clockwise hysteretic patterns have been attributed to early flushing and depletion effects as well as changes in the connectivity of riparian or hillslope flowpaths (Hornberger et al., 1994; Boyer et al., 2000; Ågren et al., 2008; Pacific et al., 2010; McGlynn and McDonnell, 2003).

Only recently, field-deployable automated devices became available to analyze physico-chemical parameters of runoff in high temporal resolution. From such measurements, new insights in the hydrological, chemical and biological controls of runoff chemistry might emerge (Kirchner et al., 2004; Halliday et al., 2012). Using high frequency measurements of DOC quality parameters, Spencer et al. (2007) found diurnal patterns which would not have been revealed by discrete sampling strategies, whereas Jeong et al. (2012), for a catchment in monsoonal climate, showed up to $23 \%$ of the annual exports of DOC and $48 \%$ of POC being realized in only a few discrete events.
The DOC export fluxes with runoff might represent a substantial contribution to the net $\mathrm{C}$ budget of ecosystems (Kindler et al., 2011). If the DOC concentration varies with discharge, the flux calculation is subjected to potential errors since discharge is often recorded permanently, while DOC concentrations are measured infrequently in larger time intervals (like fortnightly) with interpolation procedures needed for the calculation of annual fluxes (Hinton et al., 1997). Koehler et al. (2009) reported the annual DOC flux with runoff calculated from $30 \mathrm{~min}$ measurements to be similar to infrequent samplings once a day, once a week and once a month. In case of mineral elements (sulfate, nitrate, chloride), that typically show more of a chemostatic behavior, fortnightly sampling of runoff was adequate to capture annual fluxes (Alewell et al., 2004).

The objectives of this study were thus (1) to quantify the effect of hydrological conditions on DOC variations in runoff from a forested watershed, (2) to identify the compartmental origin of DOC in runoff, and (3) to investigate the implications of the short-term variations for the calculation of DOC export fluxes at the annual scale.

To these ends we have studied the relationship between DOC, discharge and groundwater level in a forested headwater catchment based on high temporal resolution techniques.

\section{Material and methods}

\subsection{Study site}

The Lehstenbach catchment is located in the Fichtelgebirge region $\left(50^{\circ} 8^{\prime} 35^{\prime \prime} \mathrm{N}, 11^{\circ} 52^{\prime} 8^{\prime \prime} \mathrm{E}\right)$ in southeastern Germany (Frei et al., 2010). The catchment area is $4.2 \mathrm{~km}^{2}$ with elevations ranging from 695 to $877 \mathrm{~m}$ above sea level. Mean annual precipitation is $1150 \mathrm{~mm}(1971-2000)$. The annual temperature averages at $5.3^{\circ} \mathrm{C}(1971-2000)$. During winter a substantial snow cover develops regularly.

The bedrock is variscan granite. Most abundant soil types are Dystric Cambisols, Haplic Podsols and Histosols (IUSS, 2007). About one third of the catchment area is covered by Histosols, mostly by minerotrophic fens with some bogs in between (in the following referred to as riparian wetland soils). The riparian wetland soils have been drained by ditches established probably in the 19th century and some active ditches still exist.

Norway spruce (Picea abies (L.) KARST.) covers approx. $90 \%$ of the catchment area. The riparian wetland soils are covered partly by Norway spruce, but also by Sphagnum mosses with patches of Vaccinium myrtillus, Juncus effusus, Carex nigra, Carex rostrata, Carex canescens, Molinia caerulea, and Eriophorum vaginatum (Matzner, 2004). 


\subsection{Hydrological boundary conditions and water sampling}

In the upland areas of the catchment the mean groundwater depth is more than $10 \mathrm{~m}$. Inclination of the catchment averages at $3^{\circ}$ and surface runoff at the slopes is of minor importance (Lischeid et al., 2002). However, based on a modeling approach, Frei et al. (2010) suggested some surface runoff from the riparian wetland soils.

Precipitation was continuously recorded in the upper part of the catchment by a tipping bucket rain gauge. The shallow groundwater level was measured in the riparian wetland soils about $2 \mathrm{~m}$ away from the stream using a piezometer with an immersed pressure sensor (Solinst Canada Ltd., Georgetown, Ontario, Canada). Discharge of the Lehstenbach stream was measured in $30 \mathrm{~min}$ intervals using a pressure sensor (Solinst Canada Ltd., Georgetown, Ontario, Canada) immersed at a $\mathrm{V}$ shaped weir at the catchment outlet.

Samples from shallow groundwater and soil solution in the riparian wetland soils, from deep (oxic) groundwater (4 wells, depth 3-15 m), and from upstream runoff without riparian wetlands, were taken on 4 occasions in 2011 (27 April, 18 May, 2 June, 16 June). The sampling of shallow groundwater and soil solution at these dates reflected different groundwater levels (Fig. 1). Shallow groundwater from the riparian wetland soils was sampled from a piezometer, deep groundwater was sampled from a well located in the upland forest area using an electric pump (Eijkelkamp, Giesbeek, the Netherlands), and soil solution from the riparian wetland soils was taken by suction devices (MacroRhizon, UMS GmbH, Muenchen, Germany).

DOC concentrations in the potential source compartments were largest in soil solution and shallow groundwater of the riparian wetland soils and in the Oa horizon percolates of the forest floor (Table 1). Lowest concentrations were observed in the soil solutions from deep layers of the upland forest soils and in the deep groundwater.

For time resolved sampling of runoff, we used an ISCO bottle sampler (ISCO 6712, Teledyne Isco, Inc., Lincoln, Nebraska, USA) programmed in a $2 \mathrm{~h}$ time interval. We chose samples according to DOC concentration and discharge measurements, trying to represent the rising limb of the hydrograph, DOC concentration peak and the falling limb with 510 samples per event. Samples were stored in $100 \mathrm{~mL}$ PE bottles at $2{ }^{\circ} \mathrm{C}$ until analysis. In total, 116 runoff samples were analyzed for DOC quality (26 on the same dates as groundwater samples, 90 on other occasions).

Baseflow separations were conducted using either the tool WHAT (Web-based Hydrograph Analysis Tool, https: //engineering.purdue.edu/ $\sim$ what/) or the algorithms by Chapman (1999, equation 8 and 9). The percentage of baseflow, and thus the flux of DOC during baseflow conditions, was strongly dependent on the choice of parameters. Therefore, we defined low flow conditions as discharge events below the median discharge $\left(60 \mathrm{~L} \mathrm{~s}^{-1}\right)$.

\subsection{Measurements of DOC concentrations in runoff in high temporal resolution}

DOC concentrations in runoff were measured in $30 \mathrm{~min}$ intervals from the 6 of August 2010 to the 5 of August 2011 by a spectrometric device (spectro::lyser, s::can Messtechnik $\mathrm{GmbH}$, Vienna, Austria) which was permanently immersed at the weir at the catchment outlet. A UV-VIS spectrum with a range from 200 to $732 \mathrm{~nm}$ was recorded every $2.5 \mathrm{~nm}$. DOC concentrations were calculated by the spectro::lyser software based on the inclusion of about 80 wavelengths under correction for turbidity. The spectro::lyser device was calibrated by measured DOC concentrations in runoff from the Lehstenbach. Hence, we used a customized calibration instead of a general setting. Although the spectro::lyzer could potentially also measure nitrate from absorption in the UV-range, we found that this is not possible in the presence of high and variable concentrations of DOC.

For quality control, the DOC concentrations estimated by the spectro::lyser were regularly cross-checked with DOC measurements by thermo-catalytic oxidation (TOCVCPN-Analyzer, Shimadzu, Kyoto, Japan). Cross-checks were made in August, September, and November 2010 and in March, April and June 2011. The $R^{2}$ of the linear correlation between the two methods ranged from 0.95 and 0.98 and the slope of the regression was close to 1 (data not shown). As there was no drift of the DOC concentration due to environmental conditions, we decided against installing an automated cleansing system. The measuring cell was manually cleaned fortnightly.

Due to instrumental failure, no measurements of DOC concentrations were available from 25 of August 2010 to 2 of September 2010, from 8 to 23 of December 2010, and from 13 to 14 of January 2011. The missing concentration data (7\% of all measurements) were interpolated by means of an artificial neural network (software SPSS 19, Modeler 14.1, IBM, Armonk, New York, United States) using the high resolution measurements (30 min) aggregated to daily means. A multilayer perceptron model with a feed-forward algorithm, one hidden layer and five neurons was used to model the daily DOC concentration. The model was trained with a back propagation algorithm using $70 \%$ of the data. Validation of the model was done with the remaining $30 \%$ of the data. This resulted in a model efficiency of $R^{2}=0.89$ and a RMSE of $1.63 \mathrm{mg} \mathrm{L}^{-1}$. The best prediction for the daily average DOC concentrations was achieved with four input parameters on the order of (1) the precipitation sum of the 6 days before the gauging, (2) mean discharge on the day of measurement, (3) mean temperature of the 170 days before the measurement and (4) the precipitation on the day of measurement. 
Table 1. Range of DOC concentrations in different compartments of the Lehstenbach catchment.

\begin{tabular}{lll}
\hline Compartment & $\begin{array}{l}\text { Range } \\
\left(\mathrm{mg} \mathrm{L}^{-1}\right)\end{array}$ & Reference \\
\hline $\begin{array}{l}\text { Soil solution beneath Oa horizon } \\
\text { (upland forest soil) }\end{array}$ & $30-80$ & Schulze et al. (2011) \\
$\begin{array}{l}\text { Soil solution in } 90 \mathrm{~cm} \text { depth } \\
\text { (upland forest soil) }\end{array}$ & $3-5$ & Schulze et al. (2011) \\
$\begin{array}{l}\text { Soil solution in 0-30 cm depth } \\
\text { (riparian wetland soil) }\end{array}$ & $10-150$ & this study \\
$\begin{array}{l}\text { Soil solution in }>30 \mathrm{~cm} \text { depth } \\
\text { (riparian wetland soil) }\end{array}$ & $10-80$ & this study \\
$\begin{array}{l}\text { Shallow groundwater in } \\
\text { 50-100 cm depth } \\
\text { (riparian wetland soil) }\end{array}$ & $4-40$ & this study \\
$\begin{array}{l}\text { Deep groundwater } \\
\text { (3-15 m depth) }\end{array}$ & $0.8-3$ & this study \\
Catchment runoff & $3-34$ & this study \\
\hline
\end{tabular}

\subsection{DOC fluxes with runoff}

Annual fluxes of DOC with runoff were calculated by multiplying the $30 \mathrm{~min}$ discharge with the corresponding $30 \mathrm{~min}$ DOC concentrations, and then cumulated to the annual flux. Due to instrumental failure no concentrations were available for 27 days. For these days the fluxes were calculated with daily average concentrations derived from the artificial neural network interpolation (see above). The interpolated data accounted for $7 \%$ of the annual flux.

To simulate the effect of infrequent sampling strategies on the calculation of annual runoff fluxes, the 30-min records of concentrations and discharge were used. To do so, the starting dates were shifting from the 6 of August 2010 to the 12 of August 2010. Furthermore, different time resolution of samplings ranging from $30 \mathrm{~min}, 1 \mathrm{~h}, 1,2,4,7$ and 14 days were simulated for each starting date. The data from these artificially created observations were inserted into the Method 5-equation of Walling and Webb (1985) (Eq. 1) to calculate the annual flux.

$F=K \cdot Q_{r} \cdot\left(\frac{\sum_{i=1}^{n} C_{i} Q_{i}}{\sum_{i=1}^{n} Q_{i}}\right)$,

where $F$ stands for the annual DOC flux; $K$ stands for the conversion factor (here number of seconds in the corresponding period of time); $Q_{r}$ stands for the daily mean discharge of the year; $Q_{i}$ stands for the discharge at the sampling day; $C_{i}$ stands for the DOC concentration at the sampling day; and $n$ is the number of sampling events.

\subsection{DOC quality}

To identify the compartmental origin of DOC in runoff, the quality of DOC in the potential source compartments was compared to the quality of DOC in runoff. Three-dimensional fluorescence excitation-emission matri- ces (EEMs) with subsequent evaluation by parallel factor analysis (PARAFAC, Stedmon et al., 2003) were used to characterize DOC quality. DOC samples were filtered (0.45 mum nylon, WICOM, Heppenheim, Germany) and diluted if necessary to an absorption at $254 \mathrm{~nm}<0.3$ to minimize inner filter effects (ultrapure water, Barnstead Nanopure, Dubuque, Iowa, USA). Inner filter correction was performed following McKnight et al. (2001), as implemented in the MATLAB toolbox by Cory and McKnight (2005). To this end, UV-VIS absorption scans were recorded on a Varian Cary 1E spectrophotometer (range $200-800 \mathrm{~nm}, 0.5 \mathrm{~nm}$ resolution, Varian Inc., purchased by Agilent Technologies, Santa Clara, California, United States). Sample correction according to the toolbox of Cory and McKnight (2005) further includes blank subtraction and normalization of fluorescence intensities to the Raman peak intensity at an excitation of $350 \mathrm{~nm}$. Raman scans, EEMs for blanks, and sample EEMs were recorded on a Perkin Elmer LS 55 fluorescence spectrometer (Waltham, Massachusetts, USA) at a resolution of $0.5 \mathrm{~nm}$ for emission $(300-600 \mathrm{~nm})$ and $5 \mathrm{~nm}$ for excitation (240-450 nm).

All data evaluation and PARAFAC modeling was done using MATLAB 2008a (MathWorks, Natick, Massachusetts, USA) and following the toolbox of Cory and McKnight (2005). Therefore, EEMs were reshaped to the appropriate resolution and range (excitation $250-400 \mathrm{~nm}, 5 \mathrm{~nm}$ steps; emission $350-440 \mathrm{~nm}, 2 \mathrm{~nm}$ steps). The PARAFAC Model from Cory and McKnight (2005) uses 13 fixed, previously identified components to describe each sample EEM. These components were found to sufficiently explain quality differences in our samples with only small residuals remaining. As a chemical molecular interpretation of the PARAFAC components identified by Cory and McKnight (2005) has become a matter of discussion (Macalady and Walton-Day, 2009), we used the 13 PARAFAC components to derive statistical fingerprints, omitting a distinct discussion about the chemical quality of the DOC of the different source compartments.

\subsection{Data analysis}

Data processing, statistical data analysis, and plotting were done in R-project version 2.13.0 (R Development Core Team, 2011) if not otherwise stated. To aggregate the $30 \mathrm{~min}$ data to daily values, we used the functions daily from the $\mathrm{R}$ project package Animal (Hanninen and Pastell, 2009) and the function $d d p l y$ from the package plyr (Wickham, 2011).

We used the classification of Butturini et al. (2008) to characterize hysteretic loops of 17 well distinct discharge events. We modified the classification of Butturini et al. (2008) such that the $\Delta C$ now is the difference between the maximum DOC concentration at a given event and the DOC concentration at low flow (first quartile of DOC concentration $\left.=5.5 \mathrm{mg} \mathrm{L}^{-1}\right) . \Delta R_{(\mathrm{DOC})}(\%)$ was calculated according to Butturini et al. (2008) and describes the area and rotational pattern of the concentration-discharge 

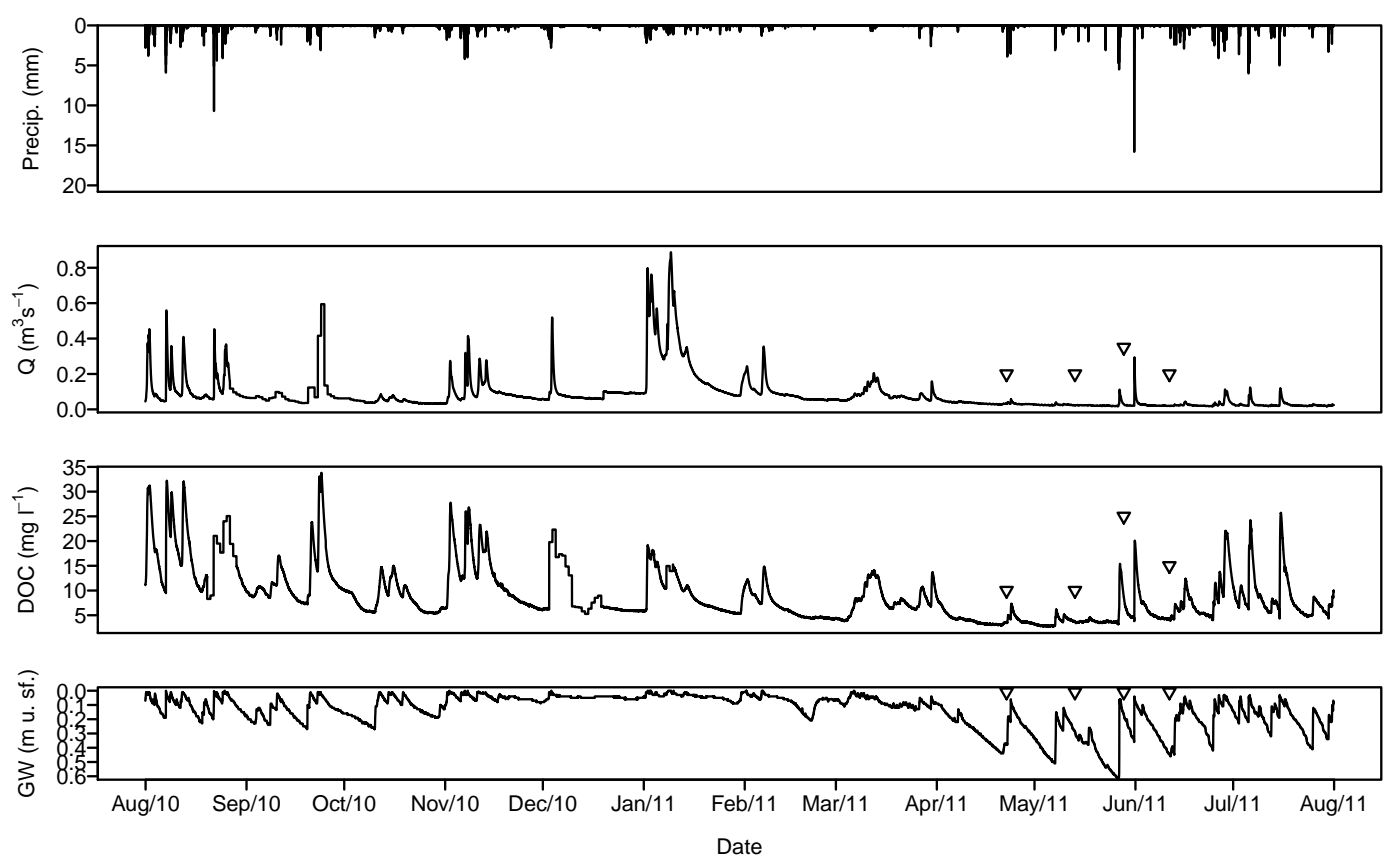

Fig. 1. Precipitation, discharge $(Q)$, DOC concentration and riparian groundwater level $(\mathrm{m} \mathrm{u} . \mathrm{sf} .=$ meter under surface) in the Lehstenbach catchment. The $\nabla$ indicate groundwater sampling dates for DOC quality analysis.

response. $\Delta R_{(\mathrm{DOC})}(\%)$ has a potential range from -100 to +100 . Negative values stand for counterclockwise loops. For $\Delta R_{(\mathrm{DOC})}(\%)$ discharge rates and DOC concentrations of each event were first normalized according to Eq. (2). Following that, each loop was rasterized by the function locator in $R$. The polygon areas were calculated by the function polyarea from the package geometry (R Development Core Team, 2011; Barber et al., 2012).

$$
X_{i, 0 \text { to } 1}=\frac{x_{i}-x_{\min }}{x_{\max }-x_{\min }}
$$

\section{Results}

\subsection{Discharge, groundwater and precipitation}

Precipitation from August 2010-August 2011 occurred at 232 days and summed up to $1057 \mathrm{~mm}$ (Fig. 1). The highest rainfall intensity was observed on the 5 of June 2011 with a rainfall of $15 \mathrm{~mm}$ within $30 \mathrm{~min}$.

Maximum discharge was $0.89 \mathrm{~m}^{-3} \mathrm{~s}^{-1}$ on the 14 of January 2011 (snow melt event), minimum discharge was $0.018 \mathrm{~m}^{-3} \mathrm{~s}^{-1}$ on the 29 of June 2011. Discharge averaged at $0.087 \mathrm{~m}^{-3} \mathrm{~s}^{-1}$. Within minutes to hours, the discharge responded to rain fall events, indicating the flashiness of the catchment (Fig. 1).

The groundwater table in the riparian wetland soils changed rapidly in response to precipitation events (Fig. 1). Groundwater was near surface in August 2010, and in the winter months 2010/2011. Lowest levels were observed on the 31 of May 2011 at $0.62 \mathrm{~m}$ below surface.

\subsection{DOC concentrations}

During the one-year period, DOC concentrations in runoff averaged at $9.2 \mathrm{mg} \mathrm{L}^{-1}$. The minimum was $2.6 \mathrm{mg} \mathrm{L}^{-1}$ in May 2011 , and the maximum was $33.8 \mathrm{mg} \mathrm{L}^{-1}$ in September 2010 (Fig. 1). The high temporal resolution of the DOC concentrations enabled a number of observations that would have been missed by typically infrequent samplings. The concentrations of DOC changed rapidly within hours and corresponded generally to the dynamics of the groundwater table and discharge with highest concentrations observed at near surface groundwater table in the riparian wetland soils and high discharge. The maxima of the DOC concentrations in runoff had a time delay of a few hours in relation to the maxima of the groundwater table and discharge (Fig. 2). The average time delay of the DOC maxima was $160 \mathrm{~min}$ after the discharge peak and the range of delays was from 30 to $390 \mathrm{~min}$ (160 $\mathrm{min}$ on average).

The DOC in runoff in response to the discharge followed counterclockwise hysteretic loops with lower concentrations on the rising than on the falling limb. The relation of DOC to discharge on the falling limb was steady and uniform, whereas the relation during the rising limb was more variable for the different events. The hysteretic loops were more pronounced and had a steeper slope in the summer/fall than in the winter/spring period (Fig. 3a). The characterization of 17 well distinct hysteretic loops confirmed the generally larger 


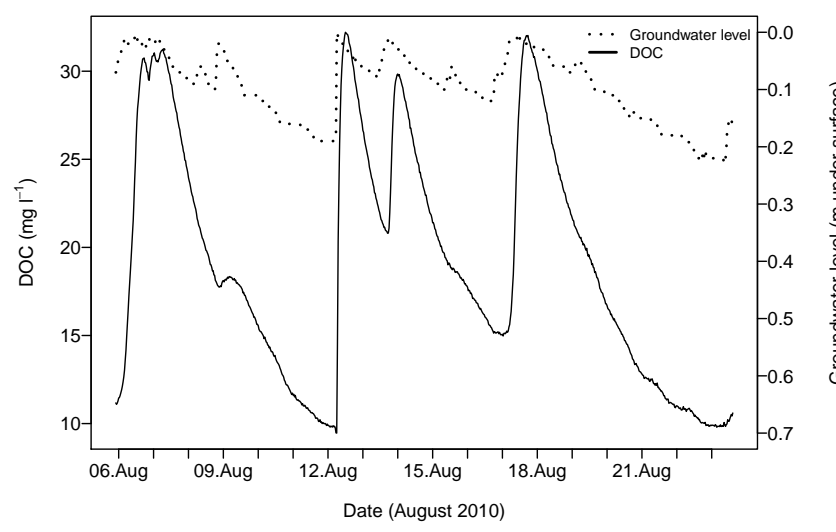

Fig. 2. Dynamics of DOC concentrations in runoff and riparian groundwater level in August 2010.

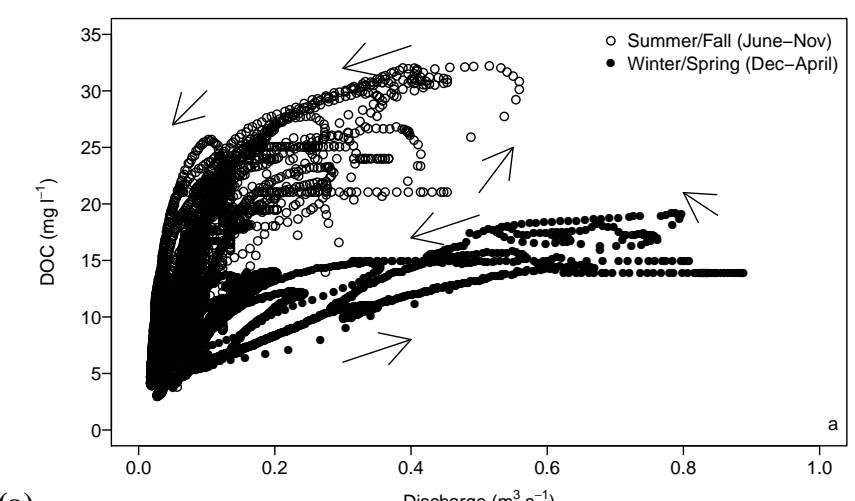

(a)

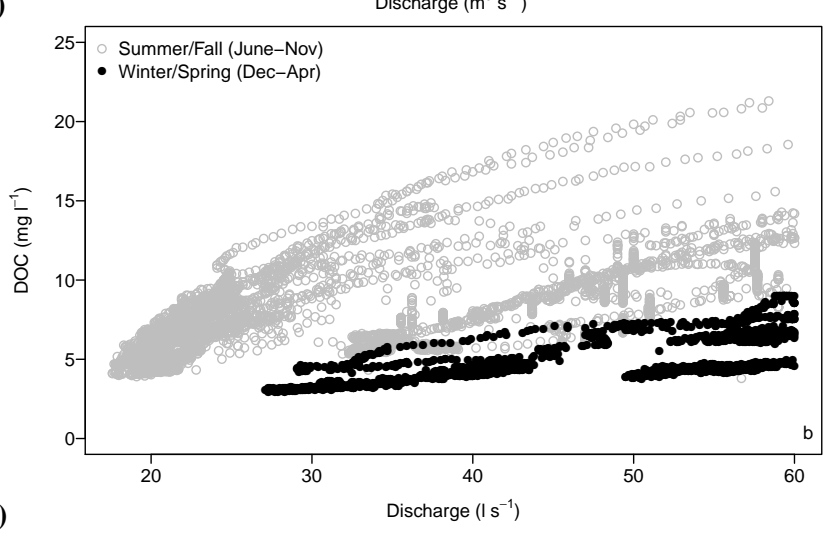

Fig. 3. (a) Counterclockwise hysteretic loops of DOC concentrations in response to discharge for summer/fall, and for winter/spring. (b) DOC concentrations response at low discharge changes $\left(<60 \mathrm{~L} \mathrm{~s}^{-1}\right)$

concentration range $(\Delta C)$ of loops in the summer/fall than in the winter/spring period (Fig. 4). All loops had a negative $\Delta R_{(\mathrm{DOC})}$ indicating the counterclockwise loops. However, single events with small discharge in summer/fall had similar loop characteristics than in the winter/spring period.

A more detailed view of the DOC/discharge relation at low flow conditions (discharge $<60 \mathrm{~L} \mathrm{~s}^{-1}$ ) and low DOC con-

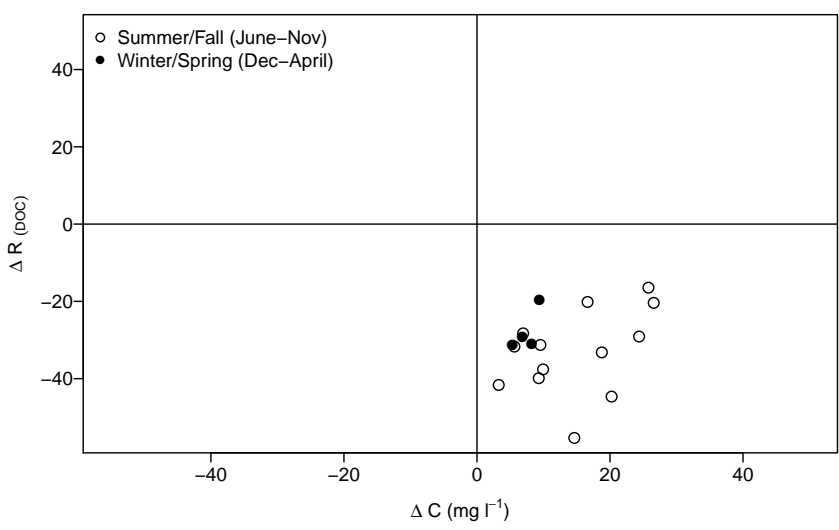

Fig. 4. Parameters of hysteretic loops in different time periods. For the calculation of $\Delta R_{(\mathrm{DOC})}$ and $\Delta C\left(\mathrm{mg} \mathrm{L}^{-1}\right)$, see Sect. 2.6.1.

centrations levels (Fig. 3b) indicates, that DOC concentrations in the summer/fall period almost directly respond to even small changes in discharge, whereas the response of DOC to discharge was smaller in the winter/spring period.

\subsection{DOC quality}

The DOC fingerprinting by fluorescence excitation-emission matrices with subsequent PARAFAC analysis clearly separated DOC originating from deep groundwater, shallow groundwater from riparian wetland soils and from runoff (Fig. 5). From the 13 fluorescence components of the applied PARAFAC Model (nomenclature according to Cory and McKnight 2005 is given in brackets), components 1 (C1), 5 (SQ1), and 6 (unidentified) were more prominent in riparian wetland samples; components 3 (unidentified), 8 (Tryptophan-like), and 12 (Q3) were more prominent in groundwater samples. Exemplarily, we used component 1 (C1, Cory and McKnight, 2005) indicative of samples from riparian wetland soils, and component 12 (Q3) as indicative of groundwater samples (other components not shown). Contribution of component 1 in DOC-fluorescence of runoff samples lined up between deep groundwater and the shallow groundwater of wetland riparian soils, suggesting a mixture of both sources, but clearly dominated by wetland-borne DOC.

Using both component 1 and component 12 (Cory and McKnight, 2005), a clear separation of samples was possible (Fig. 5), yielding 2 groups of either groundwater dominated or wetland-borne dominated DOC. While fluorescence of samples from shallow groundwater in riparian wetland soils was characterized by higher relative contribution of component 1 , deeper groundwater samples where characterized by higher contribution of component 12 . With respect to these two distinctive components, DOC quality in upstream runoff, with negligible influence from riparian wetland water and closer to a groundwater spring, was similar to deep groundwater samples (Fig. 5, open diamonds). A rise in DOC 


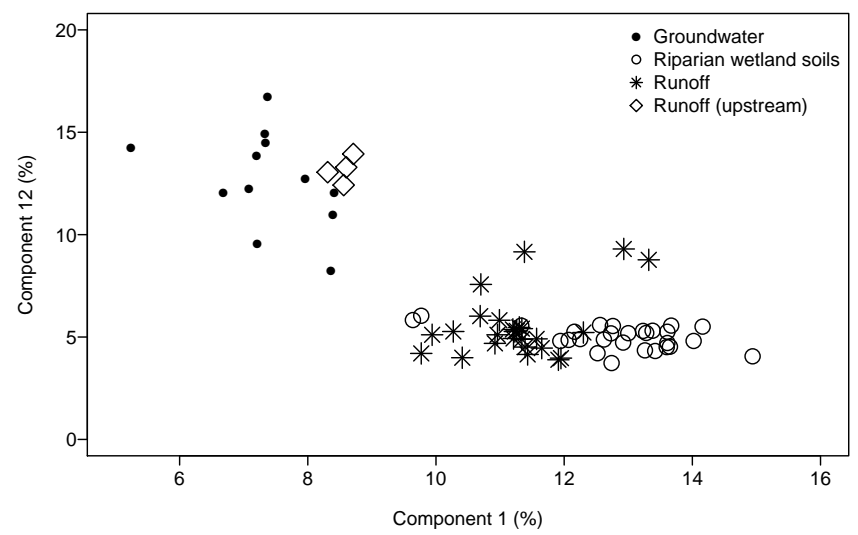

Fig. 5. Quality of DOC from different source compartments as revealed by fluorescence excitation-emission matrices and PARAFAC analysis.

concentrations with discharge always coincided with an increasing contribution of component 1 and a decrease in component 12 (Fig. 6). Even at low flow conditions $<60 \mathrm{~L} \mathrm{~s}^{-1}$ the contribution of component 1 exceeded the contribution of component 12 .

\subsection{DOC fluxes with runoff}

The cumulative DOC fluxes calculated from the $30 \mathrm{~min}$ time resolution followed generally the cumulative discharge and amounted to $84 \mathrm{~kg} \mathrm{DOC} \mathrm{ha}^{-1} \mathrm{yr}^{-1}$. However, in the summer and autumn 2010, the curve for DOC was often steeper than for discharge (data not shown).

The annual flux from the $30 \mathrm{~min}$ time resolution is taken here as the "true" reference flux. The simulated increase in sampling interval, with subsequent calculation of annual fluxes according to Eq. (1), revealed that the "true reference flux" was matched with less than $10 \%$ deviation at sampling intervals of up to 2 days. Simulated intervals $>2$ days resulted in substantial errors, with the largest range of annual fluxes observed at the fortnightly samplings (range from 57$124 \mathrm{~kg} \mathrm{DOC} \mathrm{ha}^{-1} \mathrm{yr}^{-1}$ ).

\section{Discussion}

\subsection{Range, origin and mobilization of DOC in runoff}

In comparison to other studies in forested watersheds, temporal variations and average concentrations of DOC in runoff at Lehstenbach $\left(9.2 \mathrm{mg} \mathrm{L}^{-1}\right)$ are high (Jeong et al., 2012; Koehler et al., 2009; Inamdar et al., 2012), probably due to the high proportion of wetlands in the catchment, representing a major source. Roulet et al. (2007) reported even higher average DOC concentrations of $47.5 \pm 13 \mathrm{mg} \mathrm{L}^{-1}$ in the discharge of a northern ombrotrophic bog, stressing the role of peatlands in DOC release. Short-term variations of DOC

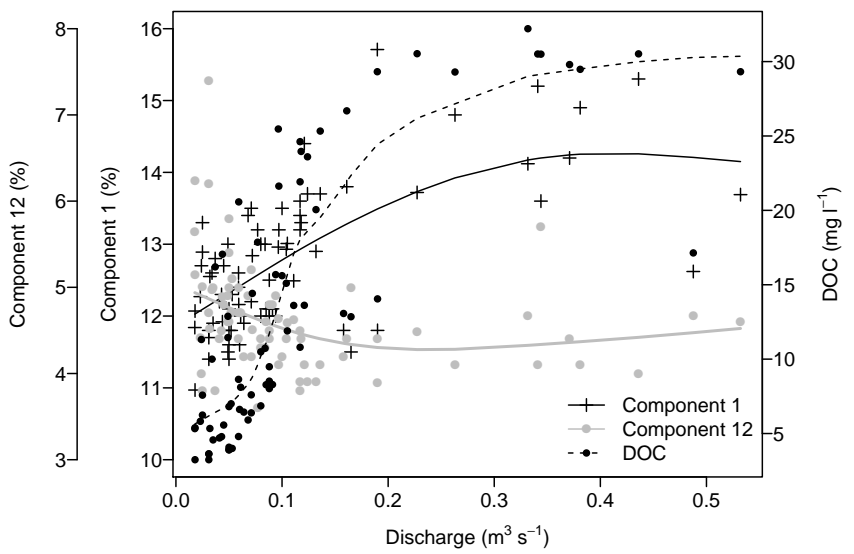

Fig. 6. DOC concentration and quality parameters in response to discharge. The lines for components 1 and 12 were fitted using the $R$ function smooth.spline and 3 degrees of freedom. The line for DOC concentrations was fitted using the $R$ function lowess with a smoothing span of $f=0.5$.

in runoff have been related to changing water flow paths under high-flow, draining different compartments than under baseflow conditions (Hood et al., 2006). In the Lehstenbach catchment, the quality of DOC, concentration range and groundwater dynamics point to the riparian wetland soils as the main source of DOC in runoff under high-flow and also under low-flow conditions, corroborating previous studies (Jaffé et al., 2008; Inamdar et al., 2012). As also reported by Inamdar et al. (2012), deep groundwater and shallow wetland groundwater differed in their contribution of fluorescence components 3 and 5 (Cory and McKnight, 2005), respectively. In our case, the best separation was achieved based on components 1 (wetland) and 12 (deep groundwater), and the decrease of the groundwater component with rising discharge and the increase of the wetland component strongly suggested the riparian wetland soils as the origin of both the fast runoff components (Frei et al., 2010) and high DOC concentration.

We have measured DOC quality in the compartments "deep groundwater" and "shallow groundwater in the riparian wetland soils" only at 4 dates. As our results agree with the findings of Inamdar et al. (2012), we are, confident that no major changes in DOC quality in these compartments can be expected. The residence time of deep groundwater in our catchment is too long (about $4 \mathrm{yr}$ ) to influence the short-term quality of DOC in runoff. The pool of DOC in the upper horizons of the wetland soils is large (we calculated a storage of about $120 \mathrm{~kg} \mathrm{DOC} \mathrm{ha}^{-1}$ wetland area in the upper $20 \mathrm{~cm}$ which will turn over only about 2 times per year) and its quality mirrors the peat quality. Lastly, the spectroscopic properties of DOC mostly result from refractory humic substances with low temporal dynamics.

Although an interpretation in a molecular sense of PARAFAC derived fluorescence components from Cory 
and McKnight (2005) seems to be limited (Macalady and Walton-Day, 2009, 2011), this approach proved to be suitable for distinguishing DOC compartmental sources in our study, when interpreting fluorescence compounds as bulk quality indices or fingerprints (Fellman et al., 2009; Inamdar et al., 2012). Following Cory and McKnight (2005), component 1 was correlated to Ketal or Acetal Carbon as analyzed by ${ }^{13} \mathrm{C}$ NMR, and component 12 to \% aliphatic carbon content. Due to its refractory character, a higher proportion of aliphatic carbon seems reasonable in groundwater with longer residence times. Fellmann et al. (2009) attributed an increase in riparian wetland-borne DOC to increases in tryptophan-like fluorescence, with tryptophan being a labile amino acid, indicating presence or proteins. According to the PARAFAC Model of Cory and McKnight (2005), who assigned component 8 to tryptophane-like fluorescence, in our dataset tryptophane-like or protein-like fluorescence was higher in deep groundwater than in shallow groundwater from riparian wetland soils. Such relative increase in protein-like fluorescence in deep groundwater samples has also been observed by Inamdar et al. (2012) suggesting that there is also bioavailable carbon in deep groundwater, although in much lower concentration. This discrepancy of our study and the study of Inamdar et al. (2012) to findings of Fellmann et al. (2009) may be explained by specific differences in the watersheds (temperate regions versus high latitudes), but it also indicates that the interpretation of PARAFAC modeling is probably not always unique and needs to be done with caution. Nevertheless, the identified fluorescence components from Cory and McKnight (2005) seemed to have more power in differentiating the source compartments of DOC than more simple optical indices (Inamdar et al., 2012).

The conclusion about the riparian wetland soils as the compartmental source for DOC in runoff is also supported by the low DOC concentrations in deeper soil layers and deep groundwater (Table 1). Forested upland soils as a potential source of peaking DOC concentrations can be ruled out since surface runoff, that could rapidly connect the upper soil layers with the streams, is not observed in the Lehstenbach catchment. The water percolating the forest floor layers enters deeper groundwater after DOC being removed largely by sorption or decomposition in the soil (Schulze et al., 2011), resulting in DOC concentrations in the groundwater of only about $1-3 \mathrm{mg} \mathrm{L}^{-1}$ (Table 1). Lastly, increasing DOC in runoff always coincided with shallow groundwater levels in the riparian wetland soils, as also observed by Morel et al. (2009) for a headwater catchment.

\subsection{Temporal dynamics of DOC in runoff}

An explanation for the observed short-term variations of DOC in runoff is the non-linear increase in catchment discharge with rising riparian groundwater levels. This increase is probably the combined effect of efficient surface flow networks that develop when groundwater levels reach surface depressions (Frei et al., 2010) and a general non-linear decrease of lateral hydraulic conductivity with depth (e.g. Seibert et al., 2009). Both mechanisms result in a rapid, nonlinear increase of drainage efficiency of the system when riparian groundwater levels are rising. The latter mechanism has been termed Transmissivity Feedback (Bishop et al., 2004) and was shown to control the transfer of solutes from the riparian zone to the streams (Seibert et al., 2009). The lateral hydraulic conductivity is typically lower in the deeper layers of wetland soils due to the compacted and more decomposed organic matter than in the porous and less decomposed shallow layers. The differences in hydraulic conductivities between deeper layers and shallow layers of wetland soils can be several orders of magnitude (Jacks and Norrström, 2004) causing shallow layers to drain much more effectively than deep soil layers. The shallow layers of the riparian wetland soils in the Lehstenbach catchment typically contain more DOC than deeper soil layers (Table 1). Rising groundwater levels in the riparian soils progressively engage soil layers with higher hydraulic conductivity and increasing DOC concentrations in the runoff generation process causing the strong response of DOC in runoff. The DOC pool available for mobilization in the riparian wetland soils seems to be large (Worrall et al., 2008) as in our study there was also no decrease in maximum DOC concentrations during subsequent rain events.

The majority of hysteretic loops in the discharge concentration response of DOC in the literature are clockwise (e.g. Hornberger et al., 1994; Butturini et al., 2006; Jeong et al., 2012). This was also reported in studies where DOC was found to originate mainly from riparian wetland soils (McGlynn and McDonnell, 2003; Hood et al., 2006). Minding the proposed Transmissivity Feedback (Bishop et al., 2004) for DOC exports and highest DOC concentrations in the riparian wetland soils, this would also be expected for our catchment. However, we observed counterclockwise hysteretic loops, with the peak of DOC concentration on the falling limb of the hydrograph. Evans and Davies (1998) used hysteretic loops to analyze episode hydrochemistry and hydrologic characteristics of catchments. According to their classification the Lehstenbach catchment falls into the category A2: Counterclockwise and positive. The A2 type requires a near surface hydrological component with lower DOC concentrations than in the soil solution and shallow groundwater of the riparian wetland soils. A similar finding with maximum concentrations of DOC on the falling limp of runoff was explained by the dilution of runoff in the initial phase of the storm by throughfall (Hagedorn et al., 2000). Beside throughfall effects, the counterclockwise hysteretic loops in our study are likely caused by the still existing ditches in the wetland soils. The restricted contact between this runoff component and the DOC-rich riparian wetland soil layers during initial runoff will result in lower DOC concentrations in the rising than in the falling limb. The effect of the bypass 
seems short-term as indicated by the few hours delay of the DOC peaks in relation to the discharge peaks.

The mobilization of DOC from soil organic matter often follows seasonal patterns with increasing concentrations during the summer. This has been shown for forest floors (Michalzik and Matzner, 1999; Gödde et al., 1996) as well as for wetland soils (Koehler et al., 2011; Clair et al., 2002). The mobilization of DOC from soil organic matter is partly driven by microbial (enzymatic) processes and partly by physicochemical processes (Bolan et al., 2011), both being temperature dependent. Hence, the steeper slope of the hysteretic loops and the more pronounced hysteresis in the summer/fall than in the winter/spring period seems largely due to a temperature effect on DOC mobilization.

In addition, the flow paths of water in the winter might be different from the summer/autumn, since the top layers of the riparian wetland soils - in summer responsible for high DOC concentrations in runoff - might not be drained due to freezing.

\subsection{Annual DOC fluxes}

The annual export of DOC from the Lehstenbach catchment $\left(84 \mathrm{~kg} \mathrm{ha}^{-1} \mathrm{yr}^{-1}\right)$ was found to be rather high in comparison to other forested watersheds. Kindler et al. (2011) calculated average DOC losses for 5 Northern European forested catchments of $35 \mathrm{~kg} \mathrm{ha}^{-1} \mathrm{yr}^{-1}$. However, Hagedorn et al. (2000) reported an export of even $185 \mathrm{~kg} \mathrm{DOC} \mathrm{ha}^{-1} \mathrm{yr}^{-1}$ from an alpine, Gleysol dominated forest ecosystem. The DOC fluxes at the Lehstenbach catchment are relatively high because of the substantial portion of riparian wetland soils. Laudon et al. (2011) defined the ratio of wetland to upland soils in boreal forested catchments as a driving variable for the DOC export. However, they suggest that the proportion of DOC from wetlands decrease with rising discharge as the contribution of water from upland zones increases. In our study we observed the opposite, since the proportion of DOC from riparian wetland soils increased with discharge, questioning the generality of the postulated relation from Laudon et al. (2011).

Depending on the precipitation regime, a substantial interannual variation of DOC exports can be expected. The longterm (1988-2008) annual discharge at Lehstenbach varied from 280 to $730 \mathrm{~mm}$ with a mean value of $460 \mathrm{~mm}$ (Lischeid et al., 2004, and unpublished data). The annual discharge in the measuring period was quite low $(360 \mathrm{~mm})$ and the fluxes in 2010/2011 may underrepresent the long-term DOC export. Nevertheless, if we take the annual DOC flux in 2010/2011 $\left(84 \mathrm{~kg} \mathrm{ha}^{-1} \mathrm{yr}^{-1}\right)$ as representative and assume that the majority originates from the riparian wetland soils $(30 \%$ of the catchment area), the export from the riparian wetland soils will be in the range of $240 \mathrm{~kg} \mathrm{DOC} \mathrm{ha}^{-1} \mathrm{yr}^{-1}$. This export equals the average $\mathrm{C}$ accumulation rates of northern peatlands (Lavoie et al., 2005), emphasizing the huge contribution of DOC exports to the $\mathrm{C}$ budget of wetland ecosystems.
Under conditions comparable to those of the Lehstenbach catchment, massive errors in calculating annual DOC export fluxes are likely if based on infrequent samplings at intervals $>2$ days, with fluxes varying up to factor 3 if fortnightly random samplings were simulated. The effect of sampling strategy on the accuracy of annual fluxes will depend on catchment characteristics, the slope of the discharge/concentration relation, the discharge dynamics and a general recommendation cannot be made. Under differing conditions in an Atlantic bog catchment, a weekly or even monthly sampling frequency was adequate to calculate the yearly DOC flux with runoff (Koehler et al., 2009).

The DOC concentrations and fluxes in the Lehstenbach runoff had a general increasing trend in the recent decades like in many other forested watersheds in Europe and North America (Skjelkvåle et al., 2005; SanClements et al., 2012). The increase in case of the Lehstenbach amounted to about $0.3 \mathrm{mg} \mathrm{L}^{-1} \mathrm{yr}^{-1}$ from 1987 to 2010 (data not shown). The increasing trend likely resulted from decreasing deposition of $\mathrm{S}$ in the past decades, increased $\mathrm{pH}$ of the precipitation and lower ionic strength of soil solutions causing enhanced mobilizing of DOC from soil organic matter (Monteith et al., 2007; Clark et al., 2011). With regard to future developments of DOC exports, we expect further increasing DOC concentrations and export fluxes: as mentioned above, the general temperature rise likely triggers DOC release from the source compartments. Temperature rise will be especially relevant in winter, because of expected changes in snow cover and more frequent water flow through DOC rich soil compartments in the less frozen soils of the future (Campbell et al., 2010). On top of that, predicted changes in summerly precipitation patterns towards longer periods of drought and more frequent high precipitation and discharge events (IPCC, 2007) will likely also result in increasing DOC exports from the Lehstenbach catchment.

\section{Conclusions}

The high frequency measurements of DOC in the Lehstenbach catchment revealed substantial variations of concentrations at hourly to daily time scales. Concentrations increased with discharge in counterclockwise, hysteretic loops, the degree of hysteresis and the response of concentrations being more pronounced in the summer/fall than in the winter/spring period. The DOC export in runoff originated mainly from the riparian wetland soils, and represents a major contribution to their overall $\mathrm{C}$ budget.

Calculations of annual DOC fluxes with runoff, if based on infrequent samplings, are prone to significant errors if steep concentration/discharge relations exist.

Predicted climatic changes, like more frequent intensive precipitation and discharge events, and the generally rising temperatures likely will enlarge the DOC export from this catchment. 
Acknowledgements. This study was financially supported by the Bavarian Environmental Agency (LfU, Landesamt für Umwelt, Hof, Germany and by the International Research Training Group TERRECO (GRK 1565/1) funded by the Deutsche Forschungsgemeinschaft (DFG). We thank Johannes Lüers and Thomas Foken (Micrometeorology, University of Bayreuth) for providing precipitation data. Further, we acknowledge the analytical work by the laboratory staff of the Department of Hydrology, University of Bayreuth, namely Martina Rohr, Jutta Eckert, Silke Hammer and Sarah Hofmann, and the help in the field work by Uwe Hell.

We are thankful to Andrea Butturini and an anonymous reviewer for their constructive comments that helped to improve the paper.

Edited by: T. J. Battin

\section{References}

Ågren, A., Buffam, I., Berggren, M., Bishop, K., Jansson, M., and Laudon, H.: Dissolved organic carbon characteristics in boreal streams in a forest-wetland gradient during the transition between winter and summer, J. Geophys. Res.-Biogeo., 113, G03031, doi:10.1029/2007JG000674, 2008.

Alewell, C., Lischeid, G., Hell, U., and Manderscheid, B.: High temporal resolution of ion fluxes in semi-natural ecosystems gain of information or waste of resources? Biogeochemistry, 69, 19-35, doi:10.1023/B:BIOG.0000031029.46798.7f, 2004.

Austnes, K., Evans, C. D., Eliot-Laize, C., Naden, P. S., and Old, G. H.: Effects of storm events on mobilisation and in-stream processing of dissolved organic matter (DOM) in a Welsh peatland catchment, Biogeochemistry, 99, 157-173, doi:10.1007/s10533009-9399-4, 2010.

Barber, C. B., Habel, K., Grasman, R., Gramacy, R. B., Stahel, A., and Sterratt, D. C.: geometry: Mesh generation and surface tesselation, R package version 0.3-2, http://CRAN.R-project.org/ package=geometry, 2012

Bishop, K., Seibert, J., Koher, S., and Laudon, H.: Resolving the double paradox of rapidly mobilized old water with highly variable responses in runoff chemistry, Hydrol. Process., 18, 185189, doi:10.1002/hyp.5209, 2004.

Bolan, N. S., Adriano, D. C., Kunhikrishnan, A., James, T., McDowell, R., and Senesi, N.: Chapter one - dissolved organic matter: Biogeochemistry, dynamics, and environmental significance in soils, Adv. Agron., 110, 1-75, doi:10.1016/B978-0-12385531-2.00001-3, 2011.

Boyer, E. W., Hornberger, G. M., Bencala, K. E., and McKnight, M. D.: Effects of asynchronous snowmelt on flushing of dissolved organic carbon: a mixing model approach, Hydrol. Process., 14, 3291-3308, 2000.

Butturini, A., Gallart, F., Latron, J., Vazquez, E., and Sabater, F.: Cross-site comparison of variability of DOC and nitrate c-q hysteresis during the autumn-winter period in three Mediterranean headwater streams: A synthetic approach, Biogeochemistry, 77, 327-349, doi:10.1007/s10533-005-0711-7, 2006.

Butturini, A., Alvarez M., Bernal, S., Vazquez, E., and Sabater, F.: Diversity and Temporal Sequences of Forms of DOC and $\mathrm{NO}_{3}$-discharge Responses in an Intermittent Stream: Predictable or Random Succession?, J. Geophys. Res., 113, G03016, doi:10.1029/2008JG000721, 2008.
Campbell, J. L., Ollinger, S. V., Flerchinger, G. N., Wicklein, H., Hayhoe, K., and Bailey, A. S.: Past and projected future changes in snowpack and soil frost at the Hubbard Brook Experimental Forest, New Hampshire, USA, Hydrol. Proc., 24, 2465-2480, doi:10.1002/hyp.7666, 2010.

Chapman, T.: A Comparison of Algorithms for Stream Flow Recession and Baseflow Separation, Hydrol. Process., 714, 701-714, 1999.

Clair, T. A., Arp, P., Moore, T. R., Dalva, M., and Meng, F. R.: Gaseous carbon dioxide and methane, as well as dissolved organic carbon losses from a small temperate wetland under a changing climate, Environ. Pollut., 116, S143-S148, doi:10.1016/S0269-7491(01)00267-6, 2002.

Clark, J. M., Van Der Heijden, G. M. F., Palmer, S. M., Chapman, P. J., and Bottrell, S. H.: Variation in the sensitivity of DOC release between different organic soils following $\mathrm{H}_{2} \mathrm{SO}_{4}$ and seasalt additions, Eur. Soil Sci., 62, 267-284, doi:10.1111/j.13652389.2010.01344.x, 2011.

Cory, R. M. and McKnight, D. M.: Fluorescence spectroscopy reveals ubiquitous presence of oxidized and reduced quinones in dissolved organic matter, Environ. Sci. Technol., 39, 8142-8149, doi:10.1021/es0506962, 2005.

Degens, E. T., Kempe, S., and Richey, J.: Biogeochemistry of major world rivers : Summary, in: Biogeochemistry of Major World Rivers, edited by: Degens, E. T., Kempe, S., and Richey, J., SCOPE Report 42, 323-347, J. Wiley \& Sons, Chichester, New York, Brisbane, Toronto, Singapore, 1991.

Evans, C. and Davies, T. D.: Causes of concentration/discharge hysteresis and its potential as a tool for analysis of episode hydrochemistry, Water Resour. Res., 34, 129-137, doi:10.1029/97WR01881, 1998.

Fellman, J. B., Hood, E., Edwards, R. T., and D'Amore, D. V.: Changes in the concentration, biodegradability, and fluorescent properties of dissolved organic matter during stormflows in coastal temperate watersheds, J. Geophys. Res.-Biogeo., 114, GO1021, doi:10.1029/2008JG000790, 2009.

Frei, S., Lischeid, G., and Fleckenstein, J. H.: Effects of microtopography on surface-subsurface exchange and runoff generation in a virtual riparian wetland - A modeling study, Adv. Water Resour., 33, 1388-1401, doi:10.1016/j.advwatres.2010.07.006, 2010.

Gödde, M., David, M. B., Christ, M. J., Kaupenjohann, M., and Vance, G. F.: Carbon mobilization from the forest floor under red spruce in the northeastern USA, Soil Biol. Biochem., 28, 11811189, doi:10.1016/0038-0717(96)00130-7, 1996.

Hagedorn, F., Schleppi, P., Waldner, P., and Fluhler, H.: Export of dissolved organic carbon and nitrogen from Gleysol dominated catchments - the significance of water flow paths, Biogeochemistry, 50, 137-161, doi:10.1023/A:1006398105953, 2000.

Halliday, S. J., Wade, A. J., Skeffington, R. A., Neal, C., Reynolds, B., Rowland, P., Neal, M., and Norris, D.: An analysis of longterm trends, seasonality and short-term dynamics in water quality data from Plynlimon, Wales, Sci. Total Environ., 434, 186-200, doi:10.1016/J.scitotenv.2011.10.052, 2012.

Hanninen, L. and Pastell, M.: CowLog: open source software for coding behaviors from digital video, Behav. Res. Methods, 41, 472-476, doi:10.3758/BRM.41.2.472, 2009.

Hinton, M. J., Schiff, S. L., and English, M. C.: The significance of storms for the concentration and export of dissolved organic 
carbon from two Precambrian Shield catchments, Biogeochemistry, 36, 67-88, doi:10.1023/A:1005779711821, 1997.

Hood, E., Gooseff, M. N., and Johnson, S. L.: Changes in the character of stream water dissolved organic carbon during flushing in three small watersheds, Oregon, J. Geophys. Res.-Biogeo., 111, G01007, doi:10.1029/2005JG000082, 2006.

Hornberger, G. M., Bencala, K. E., and McKnight, D. M.: Hydrological controls on dissolved organic carbon during snowmelt in the snake river near montezuma, Colorado, Biogeochemistry, 25, 147-165, doi:10.1007/BF00024390, 1994.

Inamdar S. I., Finger, N., Singh, S., Mitchell, M., Levia, D., Bais, H., Scott, D., and McHale, P.: Dissolved organic matter (DOM) concentration and quality in a forested mid-Atlantic watershed, USA, Biogeochemistry, 108, 55-76, doi:10.1007/s10533-0119572-4, 2012.

IPCC: Climate Change 2007: Synthesis Report. Contribution of Working Groups I, II and III to the Forth Assessment Report of the Intergovernmental Panel on Climate Change, IPCC, Geneva, Switzerland, 2007.

Ishii, S. K. L. and Boyer, T. H.: Behavior of reoccurring parafac components in fluorescent dissolved organic matter in natural and engineered systems: A critical review, Environ. Sci. Technol. 46, 2006-2017, doi:10.1021/es2043504, 2012.

IUSS Working Group WRB: "World Reference Base for Soil Resources 2006, first update 2007”, Number 103, FAO, Rome, 2007.

Jacks, G. and Norrström, A.-C.: Hydrochemistry and hydrology of forest riparian wetlands, For. Ecol. Manage. 196, 187-197, doi:10.1016/j.foreco.2004.01.055, 2004.

Jaffé, R., McKnight, D., Maie, N., Cory, R., McDowell, W. H., and Campbell, J. L.: Spatial and temporal variations in DOM composition in ecosystems: The importance of long-term monitoring of optical properties. J. Geophys. Res., 113, G04032, doi:10.1029/2008JG000683, 2008.

Jeong, J.-J., Bartsch, S., Fleckenstein, J., Matzner, E., Tenhunen, J. D., Lee, S. D., Park, S. D., and Park, J.-H.: Differential storm responses of dissolved and particulate organic carbon in a mountainous headwater stream, investigated by high-frequency in-situ optical measurements, J. Geophys. Res., 117, G03013, doi:10.1029/2012JG001999, 2012.

Kalbitz, K., Solinger, S., Park, J.-H., Michalzik, B., and Matzner, E.: Controls on the dynamics of dissolved organic matter in soils: A review, Soil Sci., 165, 277-304, doi:10.1007/s10021-003-02367, 2000.

Kindler, R., Siemens, J., Kaiser, K., Walmsley, D. C., Bernhofer, C., Buchmann, N., Cellier, P., Eugster, W., Gleixner, G., Grunwald, T., Heim, A., Ibrom, A., Jones, S. K., Jones, M., Klumpp, K., Kutsch, W., Steenberg Larsen, K., Lehuger, S., Loubet, B., McKenzie, R., Moors, E., Osborne, B., Pilegaard, K., Rebmann, C., Saunders, M., Schmidt, M. W. I., Schrumpf, M., Seyfferth, J., Skiba, U., Soussana, J.-F., Sutton, M. A., Tefs, C., Vowinckel. B., Zeeman, M. J., and Kaupenjohann, M.: Dissolved carbon leaching from soil is a crucial component of the net ecosystem carbon balance, Glob. Change Biol., 17, 1167-1185, doi:10.1111/j.1365-2486.2010.02282.x, 2011.

Kirchner, J. W., Feng, X. H., Neal, C., and Robson, A. J.: The fine structure of water-quality dynamics: the (highfrequency) wave of the future, Hydrol. Process., 18, 1353-1359, doi:10.1002/hyp.5537, 2004.
Koehler, A.-K., Murphy, K., Kiely, G., and Sottocornola, M.: Seasonal variation of doc concentration and annual loss of doc from an atlantic blanket bog in south western Ireland, Biogeochemistry, 95, 231-242, doi:10.1007/s10533-009-9333-9, 2009.

Koehler, A.-K., Sottocornola, M., and Kiely, G.: How strong is the current carbon sequestration of an Atlantic blanket bog?, Glob. Change Biol., 17, 309-319, doi:10.1111/j.13652486.2010.02180.x, 2011.

Laudon, H., Berggren, M., Ågren, A., Buffam, I., Bishop, K., Grabs, T., Jansson, M., and Köhler, S.: Patterns and dynamics of dissolved organic carbon (DOC) in boreal streams: The role of processes, connectivity, and scaling, Ecosystems, 14, 880-893, doi:10.1007/s10021-011-9452-8, 2011.

Lavoie, M., Pare, D., and Bergeron, Y.: Impact of global change and forest management on carbon sequestration in northern forested peatlands, Environ. Rev., 13, 199-240, doi:10.1139/a05-014, 2005.

Lischeid, G., Kolb, A., and Alewell, C.: Apparent translatory flow in groundwater recharge and runoff generation, J. Hydrol., 265, 195-211, doi:10.1016/S0022-1694(02)00108-7, 2002.

Lischeid, G., Alewell, C., Moritz, K., and Bittersohl, J.: Trends in the input-output relations: The catchment budgets, in: Biogeochemistry of forested catchments in a changing environment: a German case study, edited by: Matzner, E., Ecol. Stud., Springer Verlag, 172, 437-456, 2004.

Ludwig, W., Probst, J. L., and Kempe, S.: Predicting the oceanic input of organic carbon by continental erosion, Global Biogeochem. Cy., 10, 23-41, doi:10.1029/95GB02925, 1996.

Macalady, D. L. and Walton-Day, K.: New light on a dark subject: On the use of fluorescence data to deduce redox states of natural organic matter (NOM), Aquat. Sci., 71, 135-143, doi:10.1007/s00027-009-9174-6, 2009.

Macalady, D. L. and Walton-Day, K.: Redox chemistry and natural organic matter (NOM): Geochemists' dream, analytical chemists' nightmare, Aquatic Redox Chemistry, Chapter 5, 85-111, ACS Symposium Series, 1071, doi:10.1021/bk-20111071.ch005, 2011.

Matzner, E.: Biogeochemistry of Forested Catchments in a Changing Environment: A German Case Study, Ecol. Stud., Springer, 172, 2004.

McGlynn, B. L. and McDonnell, J. J.: Role of discrete landscape units in controlling catchment dissolved organic carbon dynamics, Water Resour. Res., 39, 1090, doi:10.1029/2002WR001525, 2003.

McKnight, D. M., Boyer, E. W., Westerhoff, P. K., Doran, P. T., Kulbe, T., and Andersen, D. T.: Spectrofluorometric characterization of dissolved organic matter for indication of precursor organic material and aromaticity, Limnol. Oceanogr., 46, 38-48, doi:10.4319/lo.2001.46.1.0038, 2001.

Michalzik, B. and Matzner, E.: Dynamics of dissolved organic nitrogen and carbon in a Central European Norway spruce ecosystem, Eur. J. Soil Sci., 50, 579-590, doi:10.1046/j.13652389.1999.00267.x, 1999.

Monteith, D. T., Stoddard, J. L., Evans, C. D., de Wit, H. A., Forsius, M., Høgåsen, T., Wilander, A., Skjelkvåle, B. L., Feffries, D. S., Vuorenmaa, J., Keller, B., Kopacek, J., and Vesely, J.: Dissolved organic carbon trends resulting from changes in atmospheric deposition chemistry, Nature, 450, 537-540, doi:10.1038/nature06316, 2007. 
Morel, B., Durand, P., Jaffrezic, A., Gruau, G., and Molenat, J.: Sources of dissolved organic carbon during stormflow in a headwater agricultural catchment, Hydrol. Process., 23, 2888-2901, doi:10.1002/hyp.7379, 2009.

Pacific, V. J., Jencso, K. G., and McGlynn, B. L.: Variable flushing mechanisms and landscape structure control stream DOC export during snowmelt in a set of nested catchments, Biogeochemistry, 99, 193-211, doi:10.1007/s10533-009-9401-1, 2010.

Pellerin, B. A., Saraceno, J. F., Shanley, J. B., Sebestyen, S. D., Aiken, G. R., Wollheim, W. M., and Bergamaschi, B. A.: Taking the pulse of snowmelt: in situ sensors reveal seasonal, event and diurnal patterns of nitrate and dissolved organic matter variability in an upland forest stream, Biiogeochemistry, 108, 183-198, doi:10.1007/s10533-011-9589-8, 2012.

R Development Core Team: "R: A Language and Environment for Statistical Computing", R Foundation for Statistical Computing, Vienna, Austria, ISBN 3-900051-07-0, 2011.

Raymond, P. A. and Saiers, J. E.: Event controlled DOC export from forested watersheds, Biogeochemistry, 100, 197-209, doi:10.1007/s10533-010-9416-7, 2010.

Roulet, N. T., Lafleur, P. M., Richard, P. J. H., Moore, T. R., Humphreys, E. R., and Bubier, J.: Contemporary carbon balance and late holocene carbon accumulation in a northern peatland, Glob. Change Biol., 13, 397-411, doi:10.1111/j.13652486.2006.01292.x, 2007.

SanClements, M. D., Oelsner, G. P., McKnight, D. M., Stoddard, J. L., and Nelson, S. J.: New insights into the source of decadal increases of dissolved organic matter in acid-sensitive lakes of the Northeastern United States, Environ. Sci. Technol., 46, 32133219, doi:10.1021/es204321x, 2012.

Schulze, K., Borken, W., and Matzner, E.: Dynamics of dissolved organic C-14 in throughfall and soil solution of a Norway spruce forest, Biogeochemistry, 106, 461-473, doi:10.1007/s10533010-9526-2, 2011.
Seibert, J., Grabs, T., Köhler, S., Laudon, H., Winterdahl, M., and Bishop, K.: Linking soil- and stream-water chemistry based on a Riparian Flow-Concentration Integration Model, Hydrol. Earth Syst. Sci., 13, 2287-2297, doi:10.5194/hess-13-22872009, 2009.

Skjelkvåle, B. L., Stoddard, J. L., Jeffries, D. S., Tørseth, K., Høgåsen, T., Bowman, J., Mannio, J., Monteith, D. T., Mosello, R., Rogora, M., Rzychon, D., Vesely, J., Wieting, J., Wilander, A., and Worsztynowicz, A.: Regional scale evidence for improvements in surface water chemistry 1990-2001, Environ. Pollut., 137, 165-176, 2005.

Spencer, R. G. M., Pellerin, B. A., Bergamaschi, B. A., Downing, B. D., Kraus, T. E. C., Smart, D. R., Dahgren, R. A., and Hernes, P. J.: Diurnal variability in riverine dissolved organic matter composition determined by in situ optical measurement in the San Joaquin River (California, USA), Hydrol. Process., 21, 31813189, doi:10.1002/hyp.6887, 2007.

Stedmon, C. A., Markager, S., and Bro, R.: Tracing dissolved organic matter in aquatic environments using a new approach to fluorescence spectroscopy, Mar. Chem., 82, 239-254, doi:10.1016/S0304-4203(03)00072-0, 2003.

Walling, D. E. and Webb, B. W.: Estimating the discharge of contaminants to coastal waters by rivers: Some cautionary comments, Mar. Pollut. Bull., 16, 488-492, doi:10.1016/0025326X(85)90382-0, 1985.

Wickham, H.: The split-apply-combine strategy for data analysis, J. Stat. Softw., 40, 1-29, 2011.

Worrall, F., Gibson, H. S., and Burt, T. P.: Production vs. solubility in controlling runoff of DOC from peat soils - The use of an event analysis, J. Hydrol., 358, 84-95, doi:10.1016/j.jhydrol.2008.05.037, 2008. 